\title{
ECB Interest-Rate Smoothing
}

\section{Miguel Casares}

S ince launching the euro in 1999, the European Central Bank (ECB) has conducted monetary policy in a cautious, predictable manner, making small changes in targeted interest rates. Such a policy of cautious moves is called interestrate smoothing. Researchers have noticed that central banks do tend to smooth interest rates and have offered theoretical justifications for doing so (Woodford, 2003, chap. 6). One such reason is that volatile monetary policy increases the probability of reaching the zero lower bound of nominal interest rates (e.g., as in Japan) preventing additional easing.

The chart tracks the ECB's policy of interest rate smoothing as well as the Fed's policy moves over the 2000-06 period. ECB interest rates slowly fell from 4.5 percent to 2 percent in 2000-03, remained unchanged for more than two years, and then started to gently climb. Most recently, the ECB has raised interest rates 25 basis points in each of the previous two quarters. This contrasts strongly with Federal Reserve policy that made the federal funds rate swing much more markedly. The federal funds rate was cut from 6.5 percent to 1.0 percent in 2000-03 and rebounded strongly to reach 4.75 percent in March 2006.

Why has the ECB adhered to interest-rate smoothing in its monetary policy? Because the ECB does not have a long track record, pure caution might lead it to desire smooth interest rates. Two other factors might explain the practice:

- The Euro Area economy might be more sensitive to interest rate changes than the U.S. economy, allowing smaller interest rate changes to achieve monetary policy objectives. Why might this be so? First, there is a higher percentage of adjustable rate mortgages in the Euro Area. Jean Claude Trichet, governor of the ECB, recently expressed concern about the Euro Area real estate boom and the risk of a hard landing as mortgage payments rise with short-term interest rates. Second, many Euro Area governments have high debt-to-GDP ratios (remarkably high in Belgium and Italy) and large amounts of short-term debt. Hence, they are similarly exposed to interest rate fluctuations. Third, interest-rate changes might have more influence in Europe than in the United States because the Euro Area is a more open economy. In the Euro Area, exports represent around 15 percent of GDP; in the United States, it is only 10 percent. Increased interest-rate volatility could generate wider fluctuations of the euro that may have a negative impact on Euro Area trade with the rest of the world.

- Another factor in the smoothness of ECB interest rates is that growth in the Euro Area has been less variable than that in the United States. In fact, the standard deviation of Euro Area quarterly real GDP growth has been only 1.1 percent during 2000-05, while that of the United States has been 1.4 percent over the same period. Because growth rates in Euro Area countries have been unsynchronized recently-some countries have boomed while others have stagnated-average Euro Area growth has been relatively stable over time. As a result, the ECB policy actions may have been too loose for fast-growing periphery countries (Ireland, Greece, or Spain) and too tight for slow-growing core countries (France and Germany), but adequate for the Euro Area as a whole.

Woodford, Michael. Interest and Prices: Foundations of a Theory of Monetary Policy. Princeton, NJ: Princeton University Press, 2003.

Views expressed do not necessarily reflect official positions of the Federal Reserve System. 